\title{
Representasi perempuan dalam kukungan tradisi Jawa pada film Kartini karya Hanung Bramantyo
}

\author{
Alycia Putri ${ }^{1}$, Lestari Nurhajati ${ }^{2}$ \\ ${ }^{1,2}$ The London School of Public Relations, Jakarta, Indonesia
}

\begin{abstract}
ABSTRAK
Film menjadi sebuah media yang saat ini masih diminati khalayak. Melalui film, masyarakat dapat memahami fenomena apa yang pernah dan bahkan sedang terjadi berdasarkan kisah nyata atau hanya fiktif belaka. Film Kartini yang distutradarai oleh Hanung Bramantyo dan diperankan oleh Dian Sastrowardoyo sebagai sosok Kartini merupakan sebuah media yang menampilkan kisah nyata, berdasarkan sejarah kepada masyarakat. Film ini menggambarkan tentang kaum perempuan abad ke-19 yang tidak dapat bebas dan tidak setara dengan laki-laki. Namun yang menarik sosok Kartini digambarkan sebagai sosok perempuan yang bukan hanya tokoh emansipasi, tetapi juga memiliki jiwa revolusioner. Penelitian ini bertujuan untuk mengetahui bagaimana sesungguhnya film Kartini ini mampu merepresentasikan gambaran kesetaraan gender atas sosok perempuan yang berada dalam kukungan tradisi Jawa. Konsep kesetaraan gender menjadi dasar dalam penelitian ini. Gender merupakan suatu pembeda peran, fungsi, status dan tanggungjawab antara laki-laki dengan perempuan sebagai hasil dari bentukan (konstruksi) sosial budaya yang tercipta melalui proses sosialisasi dari satu generasi ke generasi. Penelitian ini menggunakan analisis wacana Sara Mills yang memiliki fokus pada wacana mengenai feminisme; bagaimana perempuan ditampilkan dalam teks, teks yang dimaksud ialah film Kartini versi Hanung Bramantyo. Hasil penelitian ini menunjukan bagaimana sesungguhnya sebuah karya film fiksi, yang disadur dari sebuah peristiwa nyata, dengan latar belakang situasi tadisi Jawa yang penuh aturan dan kolot, mampu memunculkan sosok perempuan yang memiliki kesadaran atas kesetaraan gender.
\end{abstract}

Kata-kata Kunci: Representasi; kesetaraan gender; tradisi Jawa; film kartini; analisis wacana sara mills

\section{Representation of women in the confines of Javanese Traditions in the Kartini Film by Hanung Bramantyo}

\begin{abstract}
Film becomes a media that is currently still in demand by the public in understanding phenomena that have and even are happening based on real or fictional stories. The Kartini film directed by Hanung Bramantyo and played by Dian Sastrowardoyo as Kartini presents a true story based on history to the public. This film depicts 19th-century women who cannot be free and unequal to men. But the interesting thing is, Kartini's figure is described as a woman who is not only an emancipation figure, but also has a revolutionary spirit. This study aims to find out how the Kartini film actually is able to represent gender equality for the figure of women who are in support of the Javanese tradition. The concept of gender equality is the basis of this research. Gender is a differentiator of roles, functions, status and responsibilities between men and women as a result of social and cultural construction that is created through a process of socialization from one generation to another. This study uses Sara Mills discourse analysis which focuses on discourse on feminism; how women are shown in the text, in this case the Hanung Bramantyo version of Kartini. The results of this study show how the actual work of fiction films adapted from a real event, against the background of the Javanese tradition that is full of rules and conservatives, is able to bring up the figure of women who have an awareness of gender equality.
\end{abstract}

Keywords: Representation, gender equality, Javanese tradition, kartini films, discourse analysis sara mills

Korespondensi: Alycia Putri, S.I.Kom. The London School Of Public Relations Jakarta. Jl. Kebon Jeruk 1 No.40, Taman Sari, Jakarta Barat 11160.Email: alyciaputri02@gmail.com. 


\section{PENDAHULUAN}

McQuail (2010, p.12) menyataan bahwa media massa sebagai bagian dari kebudayaan bagi banyak orang adalah sebuah saluran yang merepresentasikan dan mengekspresikan budaya dan sebagai sumber utama dari gambaran realitas sosial dan materi untuk menunjukan dan mempertahankan identitas sosial. Media massa berfungsi untuk menghibur, memberikan informasi dan sebagai alat untuk menampilkan kultur suatu wilayah.

Media komunikasi yang berupa media massa adalah tv, radio yang disebut sebagai media elektronik, majalah, koran sebagai media cetak, dan film sebagai media komunikasi massa yang ditayangkan di layar besar bioskop. Film menjadi sebuah media yang masih diminati khalayak. Melalui film, masyarakat dapat memahami fenomena apa yang pernah dan bahkan sedang terjadi berdasarkan kisah nyata atau hanya fiktif belaka.

Film juga memiliki berbagai fungsi, tidak hanya untuk hiburan, tetapi juga untuk edukatif, persuasif, dan informatif. Fungsi edukatif dapat tercapai jika film nasional memproduksi filmfilm yang mengandung sejarah bersifat objektif, atau film documenter, serta film yang diangkat dari kehidupan sehari-hari dengan seimbang (Ardianto, Komala, \& Karlinah, 2017). Sejalan dengan penjelasan di atas, dalam artikelnya,
Marta mengatakan bahwa media massa merupakan salah satu sarana bagi setiap bangsa untuk memperkenalkan perjalanan sejarahnya dari masa ke masa. Salah satu perekam jejak yang paling efektif adalah film nasional (Marta, 2015)

Film Kartini disutradarai oleh Hanung Bramantyo dan diperankan oleh Dian Sastrowardoyo sebagai Kartini, Reza Rahadian sebagai Kartono, Adinia Wirasti sebagai Soelastri, Ayushita sebagai Kardinah, dan Acha Septriasa sebagai Roekmini. Film Kartini mendapatkan 17 penghargaan dibeberapa film festival 2017. Sebanyak 13 penghargaan Piala Citra diraih oleh Film Kartini. Kateogri yang dimenangkan adalah kategori film terbaik, sutradara terbaik, penulis skenario adaptasi terbaik, pengarah sinematografi terbaik, pengarah artistik terbaik, penyunting gambar terbaik, penata suara terbaik, penata busana terbaik, penata rias terbaik, pemeran utama pria terbaik, pemeran perempuan utama terbaik, pemeran anak terbaik, dan pemeran pendukung perempuan terbaik (Film Indonesia, 2017). Selain itu film Kartini juga mendapatkan penghargaan Aktris Pendukung Pilihan Tempo, Aktor Utama Pilihan Tempo, Aktris Utama Pilihan Tempo, dan Film Bioskop Terpuji kategori pemeran pembantu wanita (Film Indonesia, 2017).

Film Kartini adalah sebuah film dengan 
penggambaran tradisional yang menceritakan sebuah drama tentang perjuangan bangsa Indonesia pada tahun 1800-an di tanah Jawa dan di bawah pemerintahan Koloni Belanda. Raden Ajeng Kartini dilahrikan pada 28 Raibul Akhir tahun Jawa 1808, bertepatan dengan 21 April 1879 (Wicaksana, 2018). Ia adalah anak dari Sosroningrat dengan Ngasirah. Kartini memiliki 2 kakak laki-laki, yaitu Raden Ayu Tjokroadisosro dan Drs. Raden Mas Sosrokartono, serta 5 adiknya, yaitu Raden Ajeng Kardinah, Raden Ajeng Kartinah, Raden Mas Sosromuljono, Raden Ajeng Sumantri, dan Raden Mas Sosrorawito.

Dalam Film Kartini, diceritakan bahwa, seorang Bupati keturunan bangsawan jika menikah dengan perempuan bangsawan disebut Raden Ayu. Anak-anak perempuan Bupati, baik dari istri bangsawan maupun bukan, jika sudah masuk dalam masa pubertas harus menjadi seorang Raden Ayu. Ketika seorang perempuan hendak menjadi Raden Ayu, ia harus menjalani pingitan dengan cara dikurung di dalam rumah sejak menstruasi pertama untuk menanti lakilaki yang berasal dari keturunan bangsawan datang melamar dan menjadikannya istri pertama, atau kedua, bahkan ketiga.

Pada abad ke-19, perempuan tidak diperkenankan untuk menjalani pendidikan yang tinggi, termasuk untuk kaum bangsawan sekalipun (Wicaksana, 2018). Kaum perempuan Jawa tidak dapat bebas, posisinya tidak setara dengan laki-laki. Pada zaman itu dapat dikategorikan sebagai kelompok yang tersingkirkan. Perempuan ningrat yang keluar dari rumah sama saja dengan menlanggar aturan adat. Menuntut ilmu adalah hal yang dianggap tabu oleh masyarakat. Perempuan diperbolehkan mencari nafkah, tetapi seringkali dipaksa nikah dengan laki-laki yang sudah beristri.

Walaupun pemikiran ayah Kartini, yaitu Sosroningrat tergolong maju, namun sebagai bupati dan pemangku adat dia mempunyai keterbatasan dan harus tetap menghormati adat istiadat. Ia ingin Kartini menjalani masa pingitan, meskipun Kartini ingin sekali berpendidikan tinggi, Kartini pun tidak dapat membantah perintah ayahnya. Kartini dikenal sebagai gadis yang tidak anggun karena cara berjalannya yang melompat lompat.

Sosok Kartinin dalam film Kartini menggambarkan sosok perempuan yang bukan hanya tokoh emansipasi, melainkan memiliki jiwa revolusioner. Sosok Kartini dalam film Kartini berusaha menghilangkan tradisi, mengangkat kaum perempuan untuk mendapat hak yang sama.Sebuah kondisi yang tidak mudah dijalani oleh tokoh Kartini. Dalam tradisi Jawa, sebagai ibu dari anak-anak kerajaan dan istri para raja Jawa Tengah Selatan, tidak hanya bertugas memastikan kelangsungan kerajaan, 
namun dituntut juga untuk melestarikan nilai - nilai budaya dan spiritual Jawa berdasarkan adat keraton dan pendidikan anak raja (Carey \& Houben, 2018)

Dari latar belakang yang tertulis atas maka penelitian ini bertujuan untuk mengetahui bagaimana sesungguhnya film Kartini ini mampu merepresentasikan gambaran kesetaraan gender atas sosok perempuan yang berada dalam kukungan tradisi Jawa.

\section{METODE PENELITIAN}

Paradigma yang digunakan di dalam penelitian ini adalah paradigma kritis. Teori kritis secara terbuka memiliki sifat politis. Teori kritis mengasumsikan bahwa dengan menganggap masyarakat, kita dapat menjadikan prioritas pada nilai-nilai manusia (Baran dan Davis, 2009).

Menurut Littlejohn teori kritis lebih dari mengamati, mendeskripsikan, atau menafsirkan (Baran dan Davis, 2009). Epistemologi teori kritis berpendapat bahwa pengetahuan hanya maju ketika ia berfungsi untuk membebaskan orang dan masyarakat dari pengaruh mereka yang lebih kuat dari pada kerumitan. Peneliti mengamati, mendeskripsikan, atau menafsirkan apa yang disampaikan oleh film Kartini yang merepresentasikan sosok perempuan yang menjalani tradisi ningrat Jawa.

Metode yang digunakan dalam penelitian ini adalah metode kualitatif dengan teori dan teknik analisis wacana krtitis Sara Mills. Setelah mendapat adegan-adegan yang dipilih, peneliti akan mencari bagaimana perempuan ditampilkan dalam teks yang menggambarkan perempuan dikala itu masih sangat kental dengan tradisi pingitan.

Penelitian kualitatif adalah penelitian yang bermaksud untuk memahami fenomena apa yang dialami oleh subjek penelitiannya, misalnya: perilaku, persepsi, motivasi, tindakan, kejadian, pengalaman, dan lain-lain dan dengan cara mendeskripsikannya ke dalam bentuk kata-kata dan bahasa dengan memanfaatkan berbagai metode alamiah (Barlian, 2016).

Dalam penelitian ini, peneliti menggunakan metode kualitatif deskriptif. Menurut Creswell penelitian deskriptif adalah metode penelitian yang berusaha untuk menggambarkan dan menginterpretasikan objek secara murni atau apa adanya. (Sudaryono, 2018).

Tujuan penelitian deskriptif adalah menggambarkan secara sistematis fakta dan karakteristik objek yang diteliti secara tepat (Sudaryono, 2018).

Menurut Sara Mills analisis wacana kritis dilihat dari tiga bagian, yaitu, posisi: subjekobjek, bagaimana satu pihak, kelompok, orang, gagasan, atau peristiwa ditampilkan dengan cara tertentu dalam wacana berita yang mempengaruhi pemaknaan ketika diterima oleh 
khalayak; posisi pembaca, bagaimana posisi pembaca ditampilkan dalam teks (Eriyanto, 2017). Teks dianggap hanya sebagai produksi dari sisi penulis tidak memiliki hubungan dengan pembaca. Pembaca hanya ditempatkan sebagai konsumen semata yang tidak mempengaruhi pembuatan suatu teks.

Kerangka Analisis, dilihat berupa subjek seseorang, yaitu satu pihak mempunyai posisi sebagai penafsir sementara pihak lain yang menjadi objek akan ditafsirkan. Pertama, bagaimana aktor sosial dalam berita ditempatkan atau diletakan dalam sebuah berita. Siapa pihak penafsir dalam teks untuk yang menjadi pemakna suatu peristiwa, dan apa akibatnya. Kedua, bagaimana posisi pembaca di dalam teks.

Unit analisis yang digunakan dalam penelitian ini adalah teks yang berupa adeganadegan dari film Kartini yang dipercaya oleh peneliti mampu menunjukan representasi tradisi Jawa untuk dianalisis. Peneliti akan mengambil sebanyak 7 scene yang menunjukan tradisi Jawa yang didalamnya sekaligus mampu merepresntasikan adanya "perlawanan" dari tokoh Kartini yang memiliki kesadaran atas kesetaraan gender.

\section{HASIL DAN PEMBAHASAN}

Sara Mills memiliki pengalaman dengan banyak menulis mengenai teori wacana, namun meletakan titik perhatiannya mengutamakan pada bacaan atau tulisan mengenai feminisme: bagaimana perempuan ditampilkan dalam teks, baik dalam novel, gambar, foto, ataupun dalam berita (Eriyanto, 2017).

Dalam buku Diskursus karya Sara Mills, menjelaskan bahwa pada abad sembilan belas, masalah perempuan dan membaca hanyalah salah satu bukti adanya kesulitan besar yang ditemukan kaum perempuan (Mills, 2007, p.120). Penanaman struktur diskursif yang dirancang untuk perempuan dengan menekankan tugas dan kewajiban mereka sebagai istri dan ibu, yang tidak memberi ruang bagi mereka untuk menegosiasikan kesenangannya (Mills, 2007).

Perspektif dalam wacana feminis adalah menunjukkan bagaimana teks sangat mungkin berada dalam menampilkan sosok atau karakter perempuan. Perempuan cenderung ditunjukkan sebagai pihak yang salah, ketidakadilan, dan buruk di dalam teks (Eriyanto, 2017).

Ada begitu banyak perbedaan di antara perempuan, antara lain perbedaan kelas, ras, usia, pendidikan, kekayaan. kategori'perempuan' sangat sulit dipertahankan, karena mungkin ada banyak perbedaan di antara perempuan dengan pria (Mills, 1998, p.3)

Analisis Wacana Kritis Sara Mills, mengedepankan feminisme, maka fokus analisisnya adalah perempuan (Brida \& Sukaesi, 
2017). Sara Mills menuliskan teori wacana, terutama mengenai feminisme. Ttitik perhatian teori ini menunjukkan bagaimana perempuan ditunjukkan dalam teks dan ditampilkan sebagai pihak yang salah dibandingkan dengan laki-laki. Analisis Sara Mills lebih tertujukkan bagaimana posisi-posisi aktor dimunculkan dalam teks, siapa yang menjadi subjek penceritaan, siapa yang menjadi objek penceritaan, dan melibatkan bagaimana pembaca dan penulis atau dalam penelitian ini pembuat film dan penonton ditampilkan (Eriyanto, 2009).

Kerangka kerja model Sara Mills mempelajari bagaimana karakter dalam teks dijelaskan oleh penulis dan melihat posisi masing-masing karakter dalam setiap konteks sosial, seperti apa ide-idenya, dan seperti apa acara itu (Brida, Sukaesi, 2017). Teori ini menghubungkan representasi perempuan dengan representasi karakter perempuan tersebut beserta identitas diri dan pengalaman perempuan secara umum (Mills, 1998).

Ariefa dan Mutiawanthi mendefinisikan representasi sebagai konsep yang mempunyai beberapa pengertian (Ariefa, Mutiawanthi, 2016). Representasi merujuk kepada proses suatu tanda. Representasi juga bisa berarti proses perubahan konsep-konsep ideologi yang abstrak dalam bentuk-bentuk yang kongkret. Representasi adalah konsep yang digunakan dalam proses sosial pemaknaan melalui sistem berupa tanda-tanda misalnya melalui dialog, tulisan, video, film, fotografi, dan sebagainya. Sehingga bisa dimaknai bahwa representasi adalah sesuatu yang penting untuk memproduksi kebudayaan. Termasuk di dalamnya adalah produksi film sebagai bagian dari kebudayaan itu sendiri.

Film yang juga merupakan media yang menghibur untuk masyarakat dan mampu menembus segala tingkat kelas sosial. Kemampuan film dapat menjangkau berbagai segmen kelas sosial, sehingga membuat film memiliki berpotensi untuk mempengaruhi masyarakat yang menikmatinya. Nilai sebuah film tidak hanya sebatas sebagai hiburan, film juga berpotensi sebagai media edukasi, yang dapat memberikan pesan pendidikan secara efektif, bahkan mampu mempengaruhi perilaku seseorang (Trianton, 2013).

Film telah menjadi bagian dari kehidupan kita. Apa yang kita kerjakan, yang kita omongkan, yang menjadi sikap kita, gaya busana yang kita kenakan, bahkan gagasangagasan yang sering kita sampaikan acap kali merupakan bentuk turunan atau variasi dari segala hal yang pernah kita lihat dalam film. Film menjadi demikian dekat dengan kehidupan kita. Inilah yang dimaksud Douglas Kellner bahwa film merupakan salah satu produk budaya media yang turut menempa identitas kita (Trianton, 2013). 
Film memberikan suatu rekonstruksi mengenai kejadian yang ingin ditunjukan oleh si pembuat film kepada penonton. Film memiliki kombinasi antara suara dan gambar. Pengalaman mental dan budaya yang dimiliki penonton juga mempengaruhi pemahaman mereka terhadap sebuah film, secara sadar maupun tidak (Pratista, 2017).

Sztompka (2017) dalam arti sempit tradisi adalah kumpulan benda materiel dan gagasan yang diberi makna khusus yang berasal dari masa lalu. Tradisi lahir melalui dua cara, yaitu, yang pertama muncul dari bawah secara spontan dan tidak diharapkan serta melibatkan banyak masyarakat. Cara kedua, yaitu muncul dari atas melalui paksaan. Sesuatu yang dianggap tradisi dipilih dan dijadikan perhatian atau dipaksakan oleh individu yang berpengaruh atau berkuasa.

Melihat konsep tradisi yang demikian ketat tersebut maka menjadi masuk akal ketika perubahan jaman selalu berkelidan dan tarik ulur dengan kehidupan tradisi. Hal ini pun terjadi di Indonesia, khususnya di tanah Jawa yang sampai sekarang masih dirasakan sangat kuat mempertahankan budaya dan kebudayaan Jawa.

Menurut Koentjaraningrat, budaya adalah keseluruhan sistem gagasan tindakan dan hasil karya manusia dengan cara belajar (Mujianto, Elmubarok, dan Sunahrowi, 2010). Budaya atau kebudayaan berasal dari bahasa Sansekerta, yaitu buddhayah, yang merupakan bentuk jamak dari buddhi (budi atau akal) diartikan sebagai hal-hal yang berkaitan dengan budi dan akal. Manusia Jawa adalah manusia yang menganggap kehadiran adanya kebudayaan Jawa. Kebudayaan Jawa dengan sendirinya tidak sama atau sejenis. Orang Jawa menyadari adanya keberagaman, bersifat daerah, sepanjang daerah Jawa Tengah dan Jawa Timur.

Keanekaragaman budaya Jawa ini sesuai dengan ciri khas, yaitu logat bahasa Jawa dan terlihat dalam unsur yang membentuknya, seperti ciri khas makanan, upacara, rumah tangga, pakaian, kesenian rakyat, dan seni suara (Hardiningtyas, 2015).

Hermawati (2007) menyebutkan bahwa budaya Jawa memiliki banyak istilah yang menempatkan posisi perempuan lebih rendah daripada laki-laki dan itu sudah tertanam dalam dalam masyarakat, sehingga dimaklumi dan diterima begitu saja. Kita bisa melihat dari film Kartini bahwa perempuan tidak diperbolehkan untuk berpendidikan tinggi dan harus menjadi istri yang patuh atas seluruh perintah suami. Dalam kebudayaan Jawa, citra, peran dan status sebagai perempuan, telah diciptakan oleh budaya. Citra bagi seorang perempuan seperti yang diidealkan oleh budaya Jawa, antara lain, lemah lembut, penurut, tidak membantah, tidak boleh "melebihi” laki-laki. Peran yang diidealkan seperti mengurus rumah tangga, 
sebagai pendukung karir suami, istri yang penurut. Citra yang dibuat untuk laki-laki antara lain, "serba tahu", sebagai panutan harus "lebih" dari perempuan, rasional, agresif. Peran lakilaki yang ideal adalah sebagai pencari nafkah keluarga, pelindung, "mengayomi”, sedangkan status idealnya adalah kepala keluarga, Raharjo, seperti yang dikutip oleh Hermawati (2007).

Kata "gender"e dapat diartikan sebagai pembeda peran, fungsi, status dan tanggungjawab antara laki-laki dan perempuan sebagai hasil dari bentukan sosial budaya yang tertanam lewat proses sosialisasi dari satu generasi ke generasi. Dengan demikian gender adalah hasil kesepakatan antar manusia dan bukan kodrat. Gender tidak bersifat kodrati, gender dapat berubah dan dapat dipertukarkan pada manusia berdasarkan budaya setempat. (Puspitawati, 2012).

Gendermengandung aturan sosial, berkaitan dengan jenis kelamin manusia, yaitu laki-laki dan perempuan. Perbedaan biologis, yaitu alat reproduksi antara laki-laki dan perempuan merupakan fungsi reproduksi yang berbeda (perempuan mengalami menstruasi, hamil, melahirkan dan menyusui; laki-laki membuahi dengan spermatozoa). Jenis kelamin biologis merupakan ciptaan Tuhan, bersifat kodrat, tidak dapat berubah, tidak dapat dipertukarkan dan berlaku sepanjang zaman (Puspitawati, 2012).

Kebudayaan yang didasari oleh budaya patriarki menafsirkan perbedaan biologis menjadi acuan dalam perilaku yang akhirnya berujung pada pembatasan hak, akses, partisipasi, kontrol dan menikmati manfaat dari sumberdaya dan informasi. Mengakibatkan tuntutan peran, tugas, kedudukan dan kewajiban yang pantas dilakukan oleh laki-laki atau perempuan dan yang tidak pantas dilakukan oleh laki-laki atau perempuan bervariasi dan ditentukan dari satu masyarakat ke masyarakat lainnya (Puspitawati, 2012).

Pada gambar 1, adegan ini yang merupakan subjek adalah Kartini kecil yang merengek karena ingin tidur dengan ibu kandungnya, sedangkan objek dalam adegan ini adalah Kartini yang dilarang tidur dengan ibu kandungnya. Ibu kandungnya dianggap pembantu dan Kartini harus memanggilnya dengan sebutan "Yu". Pembuat Film menunjukkan kisah Kartini dalam film ini bahwa Sejak kecil kartini

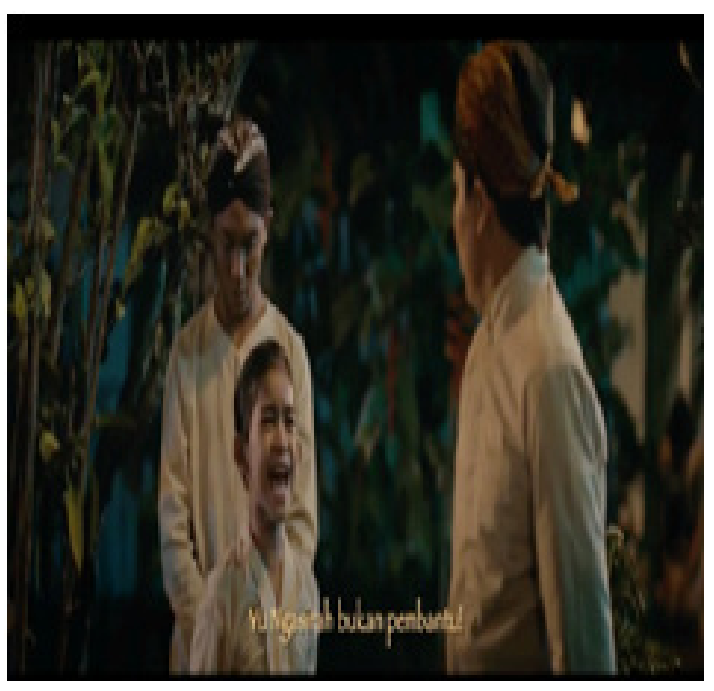

Sumber: Film Kartini, 2017

Gambar 1 Adegan Kartini Masa Kecil 
dipisahkan tempat tinggal dari ibu kandungnya. Ibu kandungnya yang bukan keturunan Ningrat tinggal di pendopo kerajaan dan statusnya dianggap sebagai pembantu rumah tangga. Dalam scene ini Kartini marah karena ingin tidur bersama ibunya dan tidak mau menyebut "Yu" (pembantu) untuk ibunya.

Dalam adegan ini perempuan dianggap sebagai objek yang tertindas, harus menurut dengan perintah suami dan tradisi. Bahkan bisa sangat direndahkan apabila status sosialnya tidak tinggi (dalam film Kartini disebut Ningrat)

Subjek dalam gambar 2, adegan ini merupakan Kartini sedang dikurung, menjalani masa pingitan, sedangkan objeknya adalah Kartini murung dan sedih, tidak menerima bahwa dirinya dipaksa menjalani masa pingitan. Pembuat Film menampilkan Perempuan dengan keturunan Ningrat Jawa ketika memasuki masa pubertas harus menjalani masa pingitan. Masa

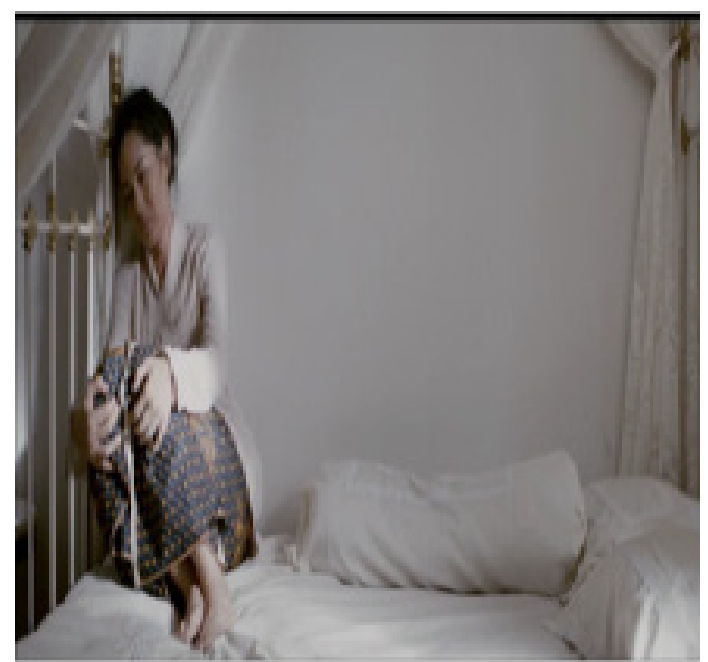

Sumber: Film Kartini, 2017

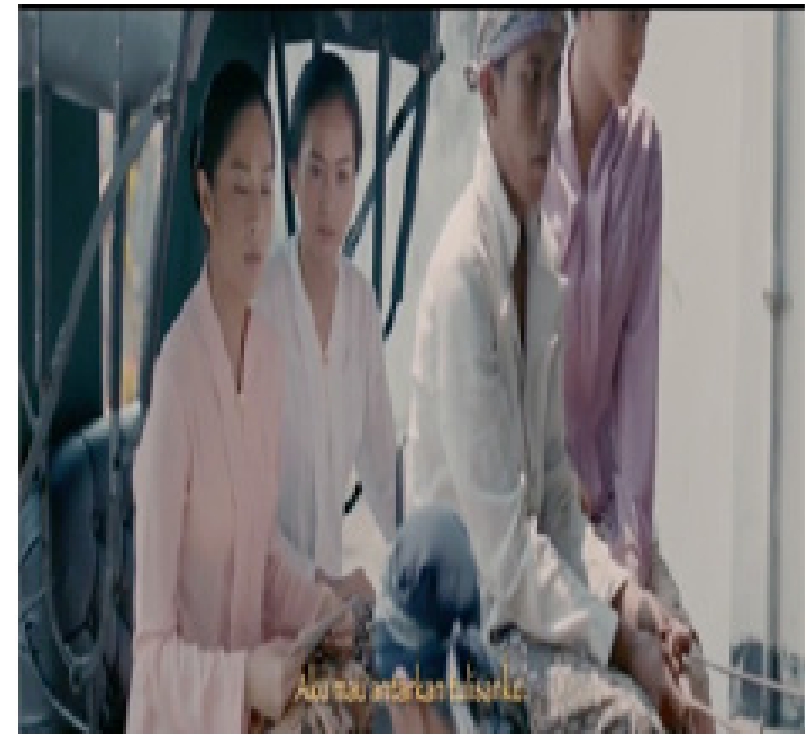

Sumber: Film Kartini, 2017

\section{Gambar 3 Adegan Kartini Mengantar Surat}

pingitan membuat Kartini sangat terbatas, ia dilarang keluar dari kompleks rumahnya, belajar jalan jongkok yang benar, dan melakukan perawatan tubuh.

Dalam adegan ini perempuan dianggap sebagai makhluk yang lemah lembut dan harus anggun. Perawatan tubuh dan jalan jongkok adalah hal utama yang harus dilakukan untuk menghormati suami.Perempuan tidak boleh meneruskan pendidikannya, agar tidak lebih unggul dari pada suaminya.

Subjek dalam gambar 3, adegan ini adalah kartini hendak mengantarkan tulisannya kepada Ny. Ter Horst, sedangkan objek pada adegan ini adalah Kartini dilarang mengantarkan surat kepada Ny. Ter Horst dan dicegat oleh Pak Atmo (penjaga gerbang pendopo). Pembuat film menampilkan Kartini hendak mengantarkan surat dan karya tulisan kepada Ny. Ter Horst. 


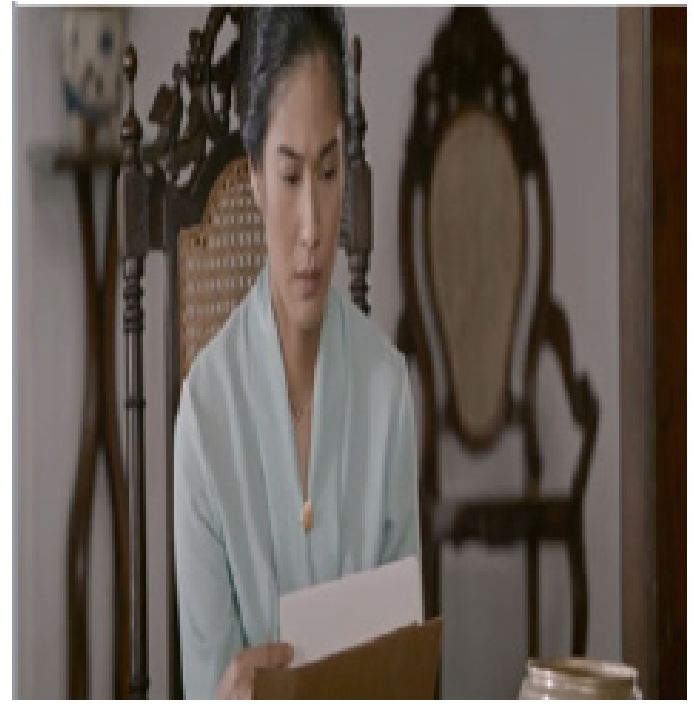

Sumber: Film Kartini, 2017

\section{Gambar 4 Adegan Kartini Dilamar}

Namun dicegat oleh Pak Atmo yang sudah ditugaskan oleh kakak laki-laki Kartini, karena kakak laki-laki Kartini tidak mau adiknya terusmenerus membuat tulisan yang akan disebarkan oleh Belanda, ia tidak mau Kartini sebagai seorang perempuan lebih berprestasi dari pada laki-laki. Adegan pada gambar 4, menunjukkan perempuan yang sedang dalam menjalani pingitan tidak boleh keluar dari pendopo, apa lagi keluar untuk alasan seperti, menjalani pendidikan atau melakukan prestasi, karena pada zaman itu perempuan tidak boleh lebih pintar dari pada laki-laki.

Subjek pada adegan gambar 5, adalah Kartini dilamar oleh Raden Adipati Joyodiningrat. Objek ddalam adegan ini adalah Kartini memberikan 4 syarat lamaran kepada Raden Adipati Joyodiningrat. Pembuat film menampilkan Kartini dilamar oleh

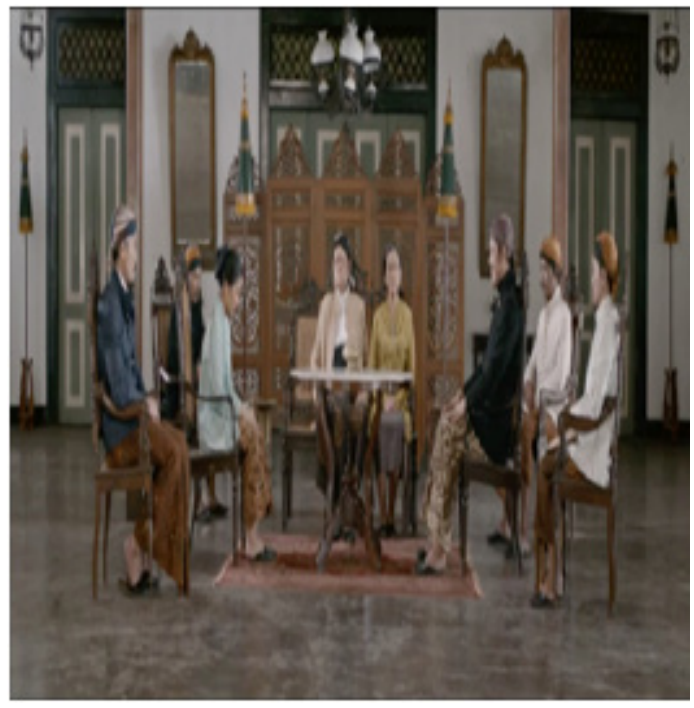

Sumber: Film Kartini, 2017

\section{Gambar 5 Adegan Kartini Dilamar}

Djojoadiningrat dan memberikan 4 syarat. Pertama, tidak mau membasuh kaki Kangmas Djoyoadiningrat disaat acara pernikahan digelar.Kedua, ingin dibebaskan dari ikatan sopan santun yang rumit dan diperlakukan sebagai orang biasa saja.Ketiga, mengharuskan calon suami membantu mendirikan sekolah untuk perempuan dan orang-orang miskin. Keempat, Kartini juga ingin Yu Ngasirah tidak tinggal di rumah belakang lagi, tetapi di rumah depan dan semua putra dan putri Romo memanggil Ngasirah dengan sebutan Mas Ajeng (Ibu). Kartini berharap kepada Raden Adipati Joyodiningrat agar syarat pernikahan tersebut tidak memicu pertentangan antar keluarga. Adegan ini menunjjukan bahwa dalam pernikahan tradisi jawa, memiliki salah satu syarat seperti mencuci kaki suami. Dalam berumah tangga juga harus menggunakan 


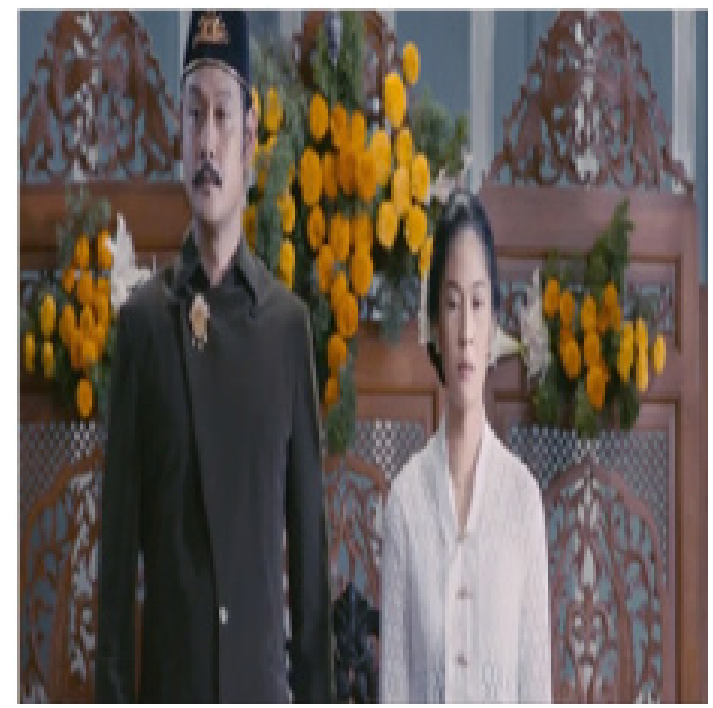

Sumber: Film Kartini, 2017

\section{Gambar 6 Adegan Kartini Menikah}

bahasa Jawa yang menunjukkan kalau istri harus takut dan patuh terhadap suami. Kartini menolak semua itu karena ia ingin diperlakukan selayaknya istri dan tidak mau direndahkan bahkan dipoligami.

Subjek pada gambar 6, adalah Kartini menikah dengan Raden Adipati Joyodiningrat, sedangkan objek pada adegan ini si pernikahan Kartini berlangsung dengan sederhana dan tidak ada tradisi mencuci kaki suami dan sungkem. Pembuat film menampilkan sosok Kartini yang menikah pada 12 November 1903 dengan Raden Adipati Joyodiningrat. Pernikahan berjalan dengan sederhana dan sesuai dengan persyaratan yang diberikan oleh Kartini saat lamaran.

Adegan pada gambar 7, menunjukkan kepada penonton bahwa pernikahan yang seharusnya sesuai dengan upacara adat, berhasil

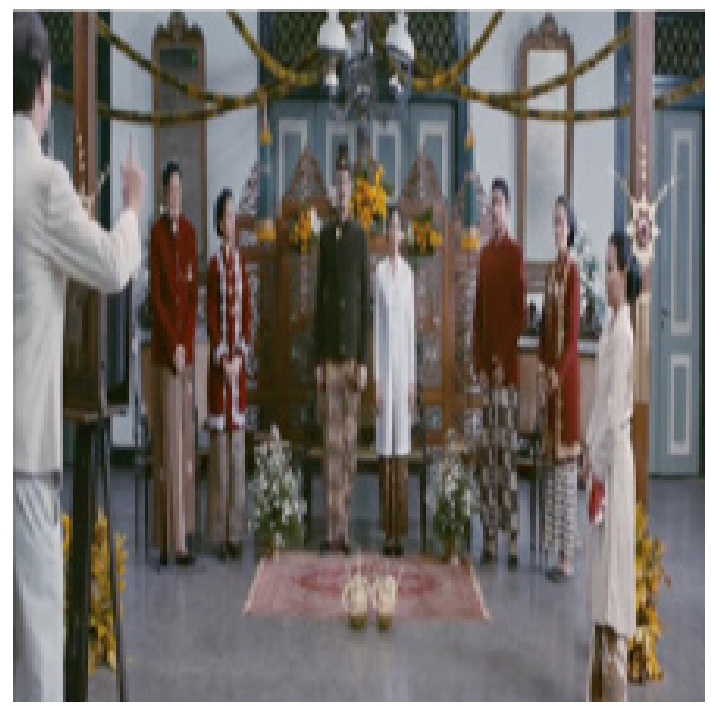

Sumber: Film Kartini, 2017

\section{Gambar 7 Adegan Kartini Menikah}

dihilangkan oleh Kartini, seperti tidak sungkem dan tidak mencuci kaki suami. Kartini dapat mengangkat keadilan untuk kaum perempuan agar tidak ditindas oleh kaum laki-laki dan tidak dipoligami oleh suami.

Penelitian ini menggunakan teknik analisis wacana kritis Sara Mills. Titik perhatian dari perspektif ini adalah menunjukkan bagaimana perempuan ditampilkan dalam teks. Perempuan cenderung ditampilkan sebagai pihak yang salah dan marjinal dibandingkan dengan lakilaki (Eriyanto, 2009). Dalam penelitian ini, representasi Perempuan Dalam Kukungan Tradisi Jawa Pada Film Kartini Karya Hanung Bramantyo terbagi menjadi 3 fokus, yaitu representasi, film, dan tradisi yang ditunjukkan dalam film Kartini.

Dalam penelitian ini pada adegan saat Kartini masih kecil, dapat dilihat bahwa sosok 
perempuan diposisikan sebagai subjek dengan menceritakan bagaimana keadaan perempuan pada tahun 1880-an dengan tradisi ningrat Jawa dibangun atas peraturan tradisi dan laki-laki sebagai sosok yang lebih berkuasa. Perempuan sebagai objek ditampilkan bahwa pada masa itu harus tunduk pada tradisi dan perintah laki-laki. Wacana ini membentuk masyarakat beranggapan bahwa perempuan yang mandiri dan menempuh pendidikan tinggi bukanlah ciri-ciri dari perempuan Indonesia. Ideologi patriarki dalam film R.A.Kartini ditampilkan melalui budaya poligami, bahasa sehari-hari dalam kebudayaan Jawa, kebungkaman sosok perempuan Jawa, serta diskriminasi yang dialami oleh perempuan Jawa.

Analisis wacana kritis Sara Mills melihat pada bagaimana perempuan ditampilkan dalam teks. Perempuan didominasi oleh laki-laki dalam tatanan sosial yang menganggap bahwa peran manusia dilihat berdasarkan kodrat. Pada adegan masa kecil Kartini, mendeskripsikan bahwa perempuan adalah makhluk yang lebih lemah dan tunduk pada perintah laki-laki. Kakak laki-laki Kartini sudah menunjukan sifat berkuasanya sebagai laki-laki dengan mengadukan Kartini kepada ayah mereka, bahwa Kartini mau tidur dengan ibu kandungnya yang dianggap sebagai pembantu dalam tradisi mereka. Ayah Kartini juga menegaskan pada Kartini bahwa ini adalah yang terakhir jika
Kartini mau tidur dengan ibunya dan harus menganggap ibunya sebagai pembantu rumah tangga.

Kebudayaan yang didasari oleh budaya patriarki menafsirkan perbedaan biologis dan menjadi patokan untuk kepantasan dalam berperilaku yang akhirnya berujung pada pembatasan hak, akses, partisipasi, kontrol dan menikmati manfaat dari sumberdaya dan informasi (Puspitawati, 2012).

Menurut Stuart Hall yang dikutip oleh Ariefa \& Mutiawanthi (dalam jurnal Al- Azhar Indonesia Seri Humaniora, 2016, Vol.3, No.3, ) representasi adalah salah satu praktek penting yang memproduksi kebudayaan. Pada adegan Kartini beserta saudara-saudara perempuannya menjalani masa pingitan, menunjukan representasi kebudayaan ningrat jawa yang menampilkan bahwa mereka harus menjalani tradisi jalan jongkok, perawatan tubuh, dan tidak boleh keluar dari pendopo.

Perempuan ditampilkan sebagai makhluk yang lemah lembut dan harus anggun Melakukan perawatan tubuh dan jalan jongkok adalah sesuatu yang menunjukkan rasa hormat kaum perempuan kepada suaminya. Pada adegan Kartini menjalani masa pingitan yang dibangun oleh pembuat film kepada penonton adalah bahwa perempuan harus menjalani beberapa tradisi pingitan, seperti dikurung dalam kamar, belajar jalan jongkok, dan 
melakukan perawatan tubuh. Tidak hanya itu saja, tetapi perempuan dilarang mengenal dunia luar dan dilarang untuk melanjutkan menuntut ilmu.

Konsep kekuasaan Jawa cenderung ke arah feminitas. Karakter perempuan Jawa sangat kental dengan kultur Jawa, seperti tutur kata yang halus, tenang, diam tidak suka berkonflik, mementingkan perdamaian, menjunjung tinggi nilai keluarga, mampu mengerti dan memahami orang lain, sopan, pengendalian diri tinggi atau terkontrol, daya tahan untuk menderita tinggi, memegang peranan secara ekonomi, dan setia atau loyalitas tinggi (Fauziyah, 2008).

Pada adegan adik Kartini, yaitu Roekmini dan Kardinah mulai memasuki masa pingitan dapatdilihatbahwapembuatfilmmenyampaikan kedua adik Kartini memiliki sifat yang berbeda dengan Kartini. Mereka berdua lebih takut dan menghormati kakaknya. Kemudian Kartini memberi nasihat kepada kedua adiknya "kita bisa menjadi Raden Ayu yang berbeda" dengan maksud adalah supaya mereka bertiga dapat bekerja sama mendapatkan keadilan untuk kaum perempuan.

Kartini, Roekmini, dan Kardinah samasama belajar dalam masa pingitan. Mereka membaca buku dan menulis dalam berbagai bahasa, seperti bahasa Indonesia, Arab, dan Belanda. Tujuan mereka adalah supaya mereka tidak tertindas oleh kaum laki-laki terutama calon suami mereka. Pada zaman itu, perempuan dilarang untuk lebih pintar dari suami, pekerjaan yang mereka lakukan adalah melayani suami dan menguruss rumah tangga, bahkan mereka harus menurut jika suami mereka ingin menikah lagi. Kartini dan adik-adik perempuannya tidak ingin hal itu terjadi kepada mereka sehingga mereka sangat berusaha keras untuk bebas menuntut ilmu dalam masa pingitannya.

Pada jaman dulu perempuan terkekang kebebasannya dalam mengekspresikan dirinya, baik di dalam keluarga maupun dalam masyarakat. Perempuan terikat oleh nilai-nilai budaya yang melekat dalam masyarakat yang tradisional (nilai-nilai budaya Jawa) (Budiati, 2010)

Dalam analisis wacana kritis Sara Mills, pada abad 19 seputar perempuan dan membaca adalah salah satu bukti adanya kesulitan besar yang ditemukan kaum perempuan dan dalam penanaman struktur diskursif dirancang untuk mereka dengan menekan tugas dan kewajiban mereka sebagai istri dan ibu, tidak memberi ruang bagi mereka untuk menegosiasikan kesenangannya (Mills, 2007). Kartini, Roekmini, dan Kardinah bersama-sama menuntut ilmu, mereka dalam keadaan sulit, tidak diberikan ruang kebebasan, tetapi mereka tetap membaca dan menulis karya.

Menurut A.P Murniati dalam Budi Susanto,dkk yang dikutip oleh Budiati (dalam 
jurnal Aktualisasi Diri Perempuan Dalam Sistem Budaya Jawa, 2010). Konsep perempuan Jawa yang lain tertuang dalam Serat Candrarini, yang dapat dirinci menjadi 9 butir: 1) Setia pada lelaki, 2) Rela dimadu, 3) Mencintai sesama, 4) Trampil pada pekerjaan perempuan, 5) Pandai berdandan dan merawat diri, 6) Sederhana, 7) Pandai melayani kehendak laki-laki, 8) Menaruh perhatian pada mertua, 9) Gemar membaca buku-buku yang berisi nasihat.

Sosok Kartini dan adik-adiknya dalam film Kartini adalah sosok perempuan yang terkekang kebebasannya. Mereka terikat oleh nilai-nilai budaya yang melekat dalam masyarakat yang tradisional (nilai-nilai budaya Jawa). Film Kartini memberikan suatu gambaran tradisional yang menceritakan perjuangan perempuan pada tahun 1800-an yang terkekang kebebasannya. Nilai-nilai budaya Jawa ditunjukkan melalui adegan pingitan yang dijalani oleh Kartini, Rukmini, dan Kardinah.

Ovink-Soer adalah sahabat Kartini. Kartini menulis surat dan bercerita banyak terutama mengenai kondisi perempuan yang dikekang adat dan tradisi. Berkat Ovink-Soer Kartini mengenal gerakan feminisme di Belanda sejak usia 20 tahun. Ovink-Soer juga yang mengenalkan Kartini dengan jurnal yang beraliran feminisme, yaitu De Hollandshce Lelie. Dalam suratnya, Kartini dapat bercerita tentang kondisi perempuan yang mengalami hal serupa dengan dirinya yang merasa terkekang, bahkan tidak bisa memilih masa depannya sendiri (Widyaningrum. L. G., April 21, 2019). Tidak hanya menulis surat dan mengirimkan karya kepada Ny. Ovink-Soer, Kartini juga menulis surat karya-karyanya kepada Ny. Ter Horst dan didukung oleh pegawai pos bernama Estella Zeehandelar

Pada adegan Kartini hendak mengantarkan tulisannya kepada Ny. Ter Horst, Kartini dicegat oleh Pak Atmo. Pak Atmo diperintahkan Ndoro Slamet untuk tidak mengizinkan Kartini dan adik-adik perempuannya keluar rumah lagi Kartini memohon setidaknya surat yang akan terbit besok sampai ke rumah Ny. Ter Horst. Pada akhirnya Pak Atmo yang mengambil surat tersebut dan ia yang akan mengantarkannya, tetapi hal itu tidak terjadi. Pak Atmo menyerahkan surat Kartini kepada Slamet dan meminta surat itu untuk dibakar.

Teori feminis menganalisis relasi kuasa dan cara bagaimana perempuan akan menegosiasikan kekuasaan tersebut, perempuan dianggap sebagai kelompok yang tertindas dan korban yang dominasi oleh laki-laki, namun melalui karya mereka mencoba cara-cara untuk menganalisis kekuasaan dengan menampakkan dirinya melalui tantangan (Mills, 2007). Film Kartini memberikan gambaran Kartini menjalani tantangannya sehari-hari yang harus diam-diam belajar di dalam masa pingitan dan 
berkarya tanpa kakak laki-lakinya mengetahui apa saja yang telah ia kerjakan.

Kedudukkan perempuan tergantung pada suami, perempuan harus tetap patuh dan taat pada perintah suami dan seterusnya akan diikuti oleh anak-anaknya, termasuk kedudukkan anak perempuan yang tergantung pada ayah atau saudara laki-lakinya (Budiati, 2010). Dalam Film Kartini, Kartini sebagai sosok perempuan yang tertindas oleh kakak laki-lakinya, berusaha menunjukkan karyanya ke dunia luar agar kaum perempuan dapat dilihat sebagai sosok yang tangguh, berpendidikan, dan memiliki kemampuan untuk berkarya.

Pada adegan Kartini mengunjungi perkampungan dibelakang pendopo, Kartini mengetahui bahwa perempuan disana banyak yang menikah diusia muda, bahkan dibawah umur, yaitu 12 tahun. Ternyata hal tersebut bukanlah hal yang diinginkan oleh mereka, melainkan karena paksaan. Mereka dijadikan istri kedua bahkan ketiga atau keempat karena ada pria dengan status ekonomi lebih tinggi dari mereka ingin menikahi dan mereka terpaksa menerima karena terdesak oleh keadaan ekonomi mereka yang sulit dikala itu.

Dalam analisis wacana kritis Sara Mills dikatakan bahwa perempuan yang bersedia dipekerjakan dalam pelbagai tugas sebagai seorang istri dan anak (perempuan), seorang ibu dan seorang teman, menjadi jauh lebih bermanfaat disbanding perempuan lainnya (Mills, 2017). Sudah kewajiban sorang perempuan menjadi sosok yang mengerjakan tugas rumah tangga dan sebagai pengasuh anak, tidak mengerjakan hal lainnya diluar itu.

Seorang perempuan Jawa dapat menerima segala situasi bahkan di situasi yang paling buruk sekalipun Mereka pintar memendam penderitaan dan memaknainya, mereka kuat dan mampu bertahan (Fauziyah, Y., 2008). Dalam film Kartini, sosok perempuan Jawa ditunjukkan sebagai makhluk yang pasrah dan tidak melakukan kegiatan lain selain mengurus rumah tangga.

Menurut Arief Budiman yang dikutip oleh Budiati (2010) tujuan perempuan hanyalah untuk menikah dan membentuk keluarg dan hampir seluruh kehidupannya diserahkan untuk keluarga. Film Kartini memberikan suatu gambaran perempuan jawa di kala itu kebebasan hidupnya terbatas karena harus menikah, tidak bisa melanjutkan pendidikannya, sehingga tujuan mereka hanya menikah dan membentuk keluarga.

Sosok Kardinah yang dipaksa menikah karena sang ayah sudah terlanjur janji dengan Bupati Tegal Pangeran Ario Reksonegoro adalah sosok perempuan yang akhirnya pasrah dan mengalah. Konsep pengakuan bagi teoretis feminis yang menganalisis perilaku dan tulisan keagamaan tentang perempuan, serta hubungan 
antara pengakuan dan kepatuhan pada yang lebih berkuasa, perempuan adalah sosok yang selalu mengalah dan mengkonstruksi dirinya sebagai subjek yang selalu mengalah (Mills, 2007).

Sosroningrat sebagai bupati dan pemangku adat harus menepati janjinya, terlebih lagi janji kepada relasinya, yaitu Bupati Tegal Pangeran Ario Reksonegoro sehingga tidak ada pilihan lain bagi Kardinah selain pasrah dan mengalah. Kartini pun sebagai sosok kakak dan pejuang kebebasan perempuan dikala itu tidak bisa berbuat apa-apa karena sosok perempuan masih dianggap rendah dan harus mematuhi tradisi yang ada.

Ajaran-ajaran dalam budaya Jawa adalah nilai-nilai budaya yang kurang mendukung posisi kesetaraan perempuan dalam kehidupan (Budiati, 2010). Perempuan Jawa diajarkan untuk menikah, melayani suami, mengurus anak dan rumah tangga beserta dengan ajaran sopan santun lainnya. Perempuan Jawa tidak dapat mengaktualisasikan dirinya, seperti yang dikutip oleh Budiati (2010) dalam Budiman (1985), "Tujuan perempuan seakan-akan hanyalah untuk menikah dan membentuk keluarga sesudahnya hamper seluruh kehidupannya dilewatkan dalam keluarga. Dalam keadaan ini perempuan jadi tergantung pada laki-laki secara ekonomis karena pekerjaan yang dilakukan di rumah tidak menghasilkan gaji, dengan ditambah lagi, perempuan seakan-akan dipenjarakan di suatu dunia yang tidak merangsang kepribadiannya."

Pada tahun 1870-an, kaum perempuan di Jawa tidak dapat bergerak leluasa di tengah masyarakat, posisinya tidak setara dengan lakilaki, harus dipingit di dalam rumah sehingga tidak dapat bersekolah di luar lagi dengan tujuan untuk menjaga harkat dan martabat sebagai perempuan (Wicaksana, 2018). Sebagai seorang perempuan yang akan menjadi Raden Ayu, Roekmini sangat takut terhadap kehidupan setelah menikah, seperti poligami dan tidak ada lagi kebebasan untuk berpendidikan. Segala usaha ia lakukan bersama sang kakak, Kartini untuk terus berkarya dan menuntut ilmu walaupun sedang dalam masa pingitan. Roekmini memohon kepada ibunya Raden Ajeng Moeryam untuk tetap bisa bersekolah, tetapi hal tersebut sangat ditolak dan tidak akan pernah terkabulkan.

Perempuan kerap kali ditampilkan sebagai pihak yang salah dibandingkan dengan pihak laki-laki (Eriyanto, 2017). Film Kartini memberikan gambaran Kartini dan adik-adik perempuannya merasa serba salah dan terdesak dengan keadaan tradisi. Mereka tetap harus mengikutin pingitan, tetapi mereka juga tahu bahwa menikah akan ada dampak buruknya bagi mereka, seperti poligami dan hilangnya kesempatan menuntut ilmu, tetapi mereka juga salah jika keluar dari rumah untuk melakukan 
kegiatan pendidikan karena itu melanggar tradisi dan melecehkan harkat dan martabat sebagai perempuan di kala itu.

MoeryambersikapkeraskepadaKartiniagar menjadi perempuan yang menuruti tradisi dan menghormati harkat dan martabat perempuan, terutama untuk calon Raden Ayu adalah gambaran bagaimana perempuan dikala itu tidak bisa lepas dari walau berusaha sekeras apa pun, seperti yang Kartini lakukan. Kartini yang tidak mengeluh dan menjalani pingitan sebagai tempat untuk mengembangkan pikirannya secara mandiri dengan membaca buku, majalah, surat kabar mengenai dunia modern, ia juga menulis esai dan surat (Wicaksana, 2018). Apa yang telah Kartini lakukan tersebut dinilai negatif oleh Raden Ajeng Moeryam. Perbuatan tersebut sangat tidak menghormati pengorbanan seorang perempuan yang telah dilakukan oleh Raden Ajeng Moeryam dahulu, yaitu menjadi istri kedua ayah Kartini karena yang selayaknya dilakukan perempuan adalah seperti yang dilakukan Raden Ajeng Moeryam dahulu.

Film Kartini menunjukkan bahwa Raden Ajeng Moeryam tidak mau merasakan tanggung jawab besar yang ia lakukan dahulu ia rasakan sendirian, ia ingin Kartini tahu bagaimana pengorbanan Raden Ajeng Moeryam untuk menjadi istri kedua. Sementara Kartni menjadi pihak yang memberontak supaya perempuanperempuan tidak lagi mengalami pemaksaan untuk menikah dan berhak mendapatkan pendidikan.

Beberapa teoretis feminis proses pembentukan subjek yang selalu mengalah tidaklah begitu sederhana, bahkan proses pembentukan diri sendiri sebagai orang yang memiliki masalah emosional, mungkin saja pada saat bersamaan akan menjadi lahan bagi munculnya perlawanan, dan mereka tidak mau melihat kesulitan itu sebagai tanggung jawab atau kesalahan mereka sendiri (Mills, 2007).

Ketika kakak Kartini, yaitu Lastri kembali ke rumah adalah suatu hal yang menyedihkan bagi seorang perempuan. Peristiwa tersebut adalah gambaran bahwa rumah tangga yang ia jalani tidak berlangsung dengan baik Berdasarkan teori Analisis Wacana Kritis Sara Mills, posisi perempuan selalu ditentukan, dan menjadi isi cerita yang tidak bisa mereka wakili sendiri. Gambar perempuan yang harus melayani suaminya, bekerja dalam rumah tangga, dan tidak bisa bebas sosialisasi biasanya tidak datang dari para perempuan itu sendiri tetapi dari aktor lain, yaitu suami atau pria.

Pada adegan Lastri kembali ke rumah orang tuanya memiliki sebab yang bukan dari Lastri sendiri. Lastri kembali ke rumah karena ia dipoligami oleh suaminya dan suaminya sudah lebih mencintai istri keduanya yang lebih pintar dari Lastri. Peran Lastri yang menangis ditampilkan bukan karena dari diri sendiri, 
tetapi dari adanya peran suami. Dalam budaya Jawa, kedudukkan perempuan khususnya dalam kehidupan rumah tangga berada di bawah bayang-bayang kekuasaan suami atau laki-laki (Budiati, 2010). Perempuan tidak memiliki hak untuk mengatur dirinya sendiri, kecuali dikehendaki oleh suaminya atau lakilaki. Kartini melihat dan tertunduk sedih dengan kejadian itu dan mempunyai 4 syarat jika ada pria yang ingin menikahinya supaya ia tidak bernasib sama dengan kakaknya.

Film Kartinimenunjukkanadanyapersoalan Gender. Adegan-adegan seperti perempuan harus rela jika dipoligami, perempuan dilarang melanjutkan pendidikan, dan kaum laki-laki yang berkuasa atas perempuan baik statusnya suami atau saudara adalah persoalan gender yang dihadapi oleh sosok Kartini dan perempuanperempuan di kala itu. Persoalan muncul ketika kesenjangan yang terjadi dalam hubungan gender telah tercipta berbagai ketidakadilan baik bagi kaum laki-laki dan terutama terhadap kaum perempuan. Ketidakadilan gender mengakibatkan perempuan kehilangan hak dan kebebasannya untuk mengambil keputusan baik itu yang menyangkut dirinya sendiri maupun untuk kepentingan khalayak luas (Hayati, 2012).

Pada adegan Kartini dilamar dan menikah dengan Djojoadiningrat. Kartini menunjukkan sikapnya yang tegas, bahwa ia berbeda dan ingin menjadikan sosok perempuan adalah sosok yang mandiri, berpendidikan, dan tidak bisa ditindas. Kartini berani bicara dan menyampaikan pendapatnya. Pada saat dilamar Kartini berani menyampaikan syarat yang diinginkannya dan hal tersebut terwujud pada saat pernikahan. Meskipun dapat dilihat wajah Kartini tidak bahagia pada saat pernikahan, ia telah berhasil menghilangkan tradisi dan sopansantun yang rumit pada saat pernikahannya.

Film Kartini menunjukkan bahwa Kartini telah melakukan banyak hal untuk melawan penindasan terhadap perempuan. Mulai dari masa pingitan ia tetap belajar, membaca, membuat tulisan dan surat untuk disebarkan ke dunia luar, dan sampai akhirnya ia dilamar oleh Djojoadiningrat dengan memberikan 4 syarat lamaran, yaitu tidak mau membasuh kaki Kangmas Djoyoadiningrat disaat acara pernikahan digelar, ingin dibebaskan dari ikatan sopan santun yang rumit dan diperlakukan sebagai orang biasa saja, mengharuskan calon suami membantu mendirikan sekolah untuk perempuan dan orang-orang miskin, Kartini juga ingin Yu Ngasirah tidak tinggal di rumah belakang lagi, tetapi di rumah depan dan semua putra dan putri Romo memanggil Ngasirah dengan sebutan Mas Ajeng (Ibu).

Kartini menginginkan adanya "pengakuan". Banyak feminis yang mencermati proses “pengakuan" yang kemudian menempatkan 
dirinya sendiri dalam sebuah kelompok kepentingan atau kelompok politik yang lebih luas (sebagai kaum feminis, atau perempuan kelas pekerja), kemudian melahirkan aksi-aksi perlawanan terhadap penindasan (Mills, 2007).

Film Kartini pada tahun 2017 ini, menampilkan tradisi yang mengikat para perempuan. Sosok Kartini ditampilkan sebagai sosok yang berani melakukan perubahan pada tradisi untuk hak kebebasan dan keadilan para perempuan. Ada perempuan yang mampu menegosiasikan keukasaan yang terlembaga da nada pula perempuan yang mendapatkan kekuasaan melalui negosiasi dengan posisi yang kelihatannya tak berdaya yang telah diberikan pada mereka (Mills, 2007).

Kaum perempuan di Indonesia masih terbelenggu oleh nilai-nilai budaya yang masih kental dan dianut dalam kehidupan, sehingga sulit bagi mereka untuk menemukan jati dirinya serta tidak berani untuk mengembangkan potensi yang dimiliki (Budiati, 2010). Persoalan ini membuat Kartini dalam film Kartni menjadi sosok yang menentang nilai-nilai tersebut. Kartini ingin mengembangkan potensi dirinya agar tidak tertindas oleh laki-laki. Ajaranajaran tradisi Jawa pada kala itu, seperti harus membasuh kaki suami pada saat prosesi pernikahan, jalan jongkok, merawat tubuh, rela dipoligami, dan aturan sopan santun lainnya dianggap Kartini cenderung memanjakan dan menikmatkan laki-laki. Hal tersebut membuat kaum laki-laki merasa lebih berkuasa dan bisa memperlakukan perempuan dengan semenamena.

Dalam film Kartini 2017, Kartini ditampilkan sebagai sosok yang tegas dan menentang didalam ketidakberdayaan perempuan, terikat dengan tradisi, banyak aturan-aturan yang membebaninya. Kartini bertekad untuk menegosiasikan keukasaan, bahwa perempuan tidak bisa ditindas terus menerus, berhak hidup bebas dan mendapatkan pendidikan. Sosok Kartini dengan keberanian dan bukti-bukti potensinya sebagai perempuan yang juga memiliki prestasi dan ilmu pengetahuan sama dengan laki-laki dapat membuktikan bahwa tidak bisa selamanya perempuan akan hidup tertindas oleh laki-laki dan tertetekan oleh tradisi.

\section{SIMPULAN}

Film Kartini karya Hanung Bramantyo menunjukkan Representasi Kesetaraan Gender Atas Sosok Perempuan Dalam Kukungan Tradisi Jawa. Terlihat dari beberapa potongan adegan yang menampilkan sosok perempuan berada di bawah kuasa laki-laki.Keadaan perempuan pada tahun 1880 -an dengan tradisi ningrat Jawa dibangun atas peraturan tradisi dan laki-laki sebagai sosok yang lebih berkuasa menunjukkan kesetaraan gender menjadi isu 
besar di masa itu.

Ideologi partriarki dalam Film Kartini ditunjukkan dalam adegan pingitan, perempuan dilarang keluar pendopo, dan seorang istri atau ibu yang bukan keturunan ningrat harus tidur di belakang rumah.

Ajaran-ajaran dalam sistem budaya Jawa adalah nilai-nilai budaya yang kurang mendukung suatu posisi perempuan untuk menjadi setara dalam berbagai sektor kehidupan (Budiati, 2010). Perempuan Jawa diajarkan untuk menikah, melayani suami, mengurus anak dan rumah tangga beserta dengan ajaran sopan santun lainnya. Perempuan Jawa tidak dapat mengaktualisasikan dirinya, seperti yang dikutip oleh Budiati (2010) dalam Budiman (1985), "Tujuan perempuan seakan-akan hanyalah untuk menikah dan membentuk keluarga sesudahnya hamper seluruh kehidupannya dilewatkan dalam keluarga. Dalam keadaan ini perempuan jadi tergantung pada laki-laki secara ekonomis karena pekerjaan yang dilakukan di rumah tidak menghasilkan gaji, dengan ditambah lagi, perempuan seakan-akan dipenjarakan di suatu dunia yang tidak merangsang kepribadiannya."

Pada tahun 1870-an, kaum perempuan di Jawa tidak dapat bergerak leluasa di tengah masyarakat, posisinya tidak setara dengan lakilaki, harus dipingit di dalam rumah sehingga tidak dapat bersekolah di luar lagi dengan tujuan untuk menjaga harkat dan martabat sebagai perempuan (Wicaksana, 2018). Sebagai seorang perempuan yang akan menjadi Raden Ayu, Roekmini sangat takut terhadap kehidupan setelah menikah, seperti poligami dan tidak ada lagi kebebasan untuk berpendidikan. Segala usaha ia lakukan bersama sang kakak, Kartini untuk terus berkarya dan menuntut ilmu walaupun sedang dalam masa pingitan. Roekmini memohon kepada ibunya Raden Ajeng Moeryam untuk tetap bisa bersekolah, tetapi hal tersebut sangat ditolak dan tidak akan pernah terkabulkan.

Perempuan cenderung ditampilkan dalam teks sebagai pihak yang salah dibandingkan dengan pihak laki-laki (Eriyanto, 2017). Film Kartini memberikan gambaran Kartini dan adik-adik perempuannya merasa serba salah dan terdesak dengan keadaan tradisi. Mereka tetap harus mengikutin pingitan, tetapi mereka juga tahu bahwa menikah akan ada dampak buruknya bagi mereka, seperti poligami dan hilangnya kesempatan menuntut ilmu, tetapi mereka juga salah jika keluar dari rumah untuk melakukan kegiatan pendidikan karena itu melanggar tradisi dan melecehkan harkat dan martabat sebagai perempuan di kala itu.

Posisi Subjek-Objek menampilkan adeganadegan film berupa peristiwa yang terjadi di masa Kartini menjadi sosok perempuan yang berada di bawah kuasa laki-laki.Penonton melihat adanya kesenjangan sosial antara 
perempuan dengan laki-laki pada film Kartini ini.

Ketidakadilan gender dalam film Kartini menyebabkan adanya kesenjangan peran yang dapat dilihat bahwa perempuan selalu tertindas oleh kaum laki-laki. Konsep adat Jawa yang membelenggu perempuan Jawa di kala itu sedikit demi sedikit diruntuhkan oleh Kartini karena sikapnya yang berani membuat perubahan dan membukakan pikiran orangorang di sekitarnya, baik laki-laki maupun perempuan tentang ketidakadilan gender.

Hasilpenelitianinidiharapkandapatmenjadi menfaat bagi akademisi yang membutuhkan terkait dengan perempuan dan kesetaraan gender. Penelitian berikutnya diharapkan dapat membahas lebih luas lagi mengenai sejarah kehidupan emansipasi perempuan, seperti pendidikan untuk perempuan dan orang miskin yang dibangun oleh Kartini. Pembaca mampu menyikapi secara bijak atas segala bentuk ketidakadilan gender antara perempuan dengan laki-laki agar tidak terjadi lagi ketidakadilan tersebut.

\section{DAFTAR PUSTAKA}

Ardianto, E, Komala, L, \& Karlinah, S. (2017). Komunikasi massa suatu pengantar. Bandung: Simbiosa Rekatama Media. Baran, J. (2009). Mass communication theory. USA: Wadsworth Cengage Learning.
Brida dan Sukaesi (2017). Assessing text alignment: sara mill's model. Jurnal Epigram. Vol. 14, No. 1, p.1. Diperoleh dari E-journal: http://jurnal.pnj.ac.id/index. php/epiepig/article/view/948

Budiati, C. A. (2010). Aktualisasi diri perempuan dalam sistem budaya Jawa. Jurnal Trunojoyo. Vol. 3, No. 1, p. 5157. Diperoleh dari E-journal: http:// journal.trunojoyo.ac.id/pamator/article/ view/2401/1990

Carey, P. (2018). Perempuan-perempuan Perkasa. Jakarta: Kepustakaan Populer Gramedia.

Eriyanto. (2009). Analisis cacana. Yogyakarta: LKiS Group.

Eriyanto. (2017). Analisis Wacana. Yogyakarta: LKiS Group.

Fauziyah, Y. (2008). Menyingkap kuasa maskulinitas di balik tabir feminitas wanita Jawa. Jurnal Ulumuna. Vol. 22, No. 1, p.194. Diperoleh dari E-journal: https:// ulumuna.or.id/index.php/ujis/article/ view/163/147

Film Indonesia.or.id (2017). Kartini. Diperoleh dari website: http://filmindonesia.or.id/ movie/title/lf-k007-17-371853_kartini/ award\#.XEdK61wzbIU.

Hardiningtyas, P. (2015). Manusia dan budaya Jawa dalam roman bumi manusia eksistensialisme pemikiran Jean Paul Sarte. JurnalAksara. Vol.27, No.1,p.25. Diperoleh dari E-journal: http://pbsi.fbs.uny.ac.id/ sites/pendidikan-bahasa-sastraindonesia. fbs.uny.ac.id/files/KUMPULAN\%20 MAKALAH\%20SEMINAR\%202017 VERSI\%20BARU\%2020517.pdf

Hermawati, T. (2007). Budaya Jawa dan kesetaraan gender. Jurnal Komunikasi Massa. Vol.1, No.1, p.21-24. Diperoleh dari E-journal: 
https://webcache.googleusercontent. com/search? q=cache:A IedpQwm R0J:https://digilib.uns.ac.id/ d o k u m e n / d own loa d/ 10734 / MjQxNDM\%3 D / B udaya-Jaw a dan-Kesetaraan-Gender-abstrak. $\mathrm{pdf}+\& \mathrm{~cd}=1 \& \mathrm{hl}=\mathrm{en} \& \mathrm{ct}=\mathrm{clnk} \& \mathrm{gl}=\mathrm{id}$

Marta, R. F. (2015). Analisis wacana kritis film "Puteri Giok": cermin asimilasi paksa era orde baru. Jurnal Masyarakat \& Budaya. 17(1), 331-346.

Mcquail, D. (2010). McQuail's mass communication theory. London: SAGE Publications.

Mills, S. (2007). Diskursus. Jakarta: Penerbit Qalam.

Mujianto, Y. Elmubarok, Z. \& Sunahrowi. (2010). Pengantar ilmu budaya. Yogyakarta: Pelangi Publishing.

Pratista, H. (2017). Memahami film. Yogyakarta: Montase Press.

Puspitawati, H. (2012). Gender dan keluarga: konsep dan realita di Indonesia. Jurnal Departemen Ilmu Keluarga dan Konsumen Fakultas Ekologi Manusia Institut Pertanian Bogor. Diperoleh dari website: http:/webcache.googleusercontent.com/ search?q=cache:Myfh47xyIJwJ:ikk.fema. ipb.ac.id/v2/images/karyailmiah/teori. $\mathrm{pdf}+\& \mathrm{~cd}=2 \& \mathrm{hl}=\mathrm{en} \& \mathrm{ct}=\mathrm{clnk} \& \mathrm{gl}=\mathrm{id}$.

Sudaryono. (2018). Metodologi penelitian. Depok: RajaGrafindo Persada.

Sztompka, P. (2018). Sosiologi peruahan Sosial. Jakarta: Prenada Media.

Trianton, T. (2013). Nilai pendidikan karakter berbasis kearifan lokal dalam film Indie Banyumas, Vol.2, No.1, p.4. Jurnal Ilmiah Kependidikan. Diperoleh dari E-journal:http://webcache. googleusercontent.com/h?q=cache:Kzo wWJ4USk0J:jurnalnasional.ump.ac.id/ index.php/khazanah/article/w/650/642+\&c $\mathrm{d}=1 \& \mathrm{hl}=\mathrm{en} \& \mathrm{ct}=\mathrm{clnk} \& \mathrm{gl}=\mathrm{id}$

Wicaksana, W, A. (2018). Raden Ajeng Kartini. Sleman, Yogyakarta: Solusi Distribusi.

Widyaningrum, L, G.: "Memahami Kepahlawanan Kartini Melalui Suratsuratnya." Diperoleh dari website: https://nationalgeographic.grid. $\mathrm{id} / \mathrm{read} / 131702956 / \mathrm{memahami-}$ kepahlawanan-kartini-melalui-suratsuratnya?page $=$ all 